\title{
Front Matter: Volume 11825
}

, "Front Matter: Volume 11825," Proc. SPIE 11825, Ultrafast Nonlinear Imaging and Spectroscopy IX, 1182501 (19 August 2021); doi:

$10.1117 / 12.2606268$

SPIE Event: SPIE Optical Engineering + Applications, 2021, San Diego, California, SPIE. United States 


\title{
PROCEEDINGS OF SPIE
}

\section{Ultrafast Nonlinear Imaging and Spectroscopy IX}

\author{
Zhiwen Liu \\ Demetri Psaltis \\ Kebin Shi \\ Editors
}

1-5 August 2021

San Diego, California, United States

Sponsored by and Published by

SPIE 
The papers in this volume were part of the technical conference cited on the cover and title page. Papers were selected and subject to review by the editors and conference program committee. Some conference presentations may not be available for publication. Additional papers and presentation recordings may be available online in the SPIE Digital Library at SPIEDigitalLibrary.org.

The papers reflect the work and thoughts of the authors and are published herein as submitted. The publisher is not responsible for the validity of the information or for any outcomes resulting from reliance thereon.

Please use the following format to cite material from these proceedings:

Author(s), "Title of Paper," in Ultrafast Nonlinear Imaging and Spectroscopy IX, edited by Zhiwen Liu, Demetri Psaltis, Kebin Shi, Proc. of SPIE 1 1825, Seven-digit Article CID Number (DD/MM/YYYY); (DOI URL).

ISSN: 0277-786X

ISSN: 1996-756X (electronic)

ISBN: 9781510644885

ISBN: 9781510644892 (electronic)

Published by

SPIE

P.O. Box 10, Bellingham, Washington 98227-0010 USA

Telephone +1 3606763290 (Pacific Time)

SPIE.org

Copyright (C) 2021 Society of Photo-Optical Instrumentation Engineers (SPIE).

Copying of material in this book for internal or personal use, or for the internal or personal use of specific clients, beyond the fair use provisions granted by the U.S. Copyright Law is authorized by SPIE subject to payment of fees. To obtain permission to use and share articles in this volume, visit Copyright Clearance Center at copyright.com. Other copying for republication, resale, advertising or promotion, or any form of systematic or multiple reproduction of any material in this book is prohibited except with permission in writing from the publisher.

Printed in the United States of America by Curran Associates, Inc., under license from SPIE.

Publication of record for individual papers is online in the SPIE Digital Library.

\section{SPIE. DIGITAL}

Paper Numbering: A unique citation identifier (CID) number is assigned to each article in the Proceedings of SPIE at the time of publication. Utilization of CIDs allows articles to be fully citable as soon as they are published online, and connects the same identifier to all online and print versions of the publication. SPIE uses a seven-digit CID article numbering system structured as follows:

- The first five digits correspond to the SPIE volume number.

- The last two digits indicate publication order within the volume using a Base 36 numbering system employing both numerals and letters. These two-number sets start with 00, 01, 02, 03, 04, 05, 06, 07, 08, 09, 0A, OB ... 0Z, followed by 10-1Z, 20-2Z, etc. The CID Number appears on each page of the manuscript. 


\section{Contents}

ULTRAFAST ELECTRON DIFFRACTION AND IMAGING

$118250 \mathrm{M}$ Femtosecond molecular dynamics viewed by multi-model imaging (Invited Paper) [1 1825-10]

1182500 Observation of conformer-specific photochemical dynamics with MeV ultrafast electron diffraction (Invited Paper) [11825-12]

ULTRAFAST SOURCES AND APPLICATIONS

11825 OT Ultrafast laser source for nonlinear imaging and spectroscopy with high energy sub-100 fs pulses [11825-18]

\section{NANOSCALE PHENOMENA}

11825 OU Single nanocrystal anti-stokes shifted superfluorescence [11825-22]

11825 OV Unidirectional optical mechano-sensing with upconversion nanoparticles (Invited Paper) [11825-21]

NOVEL ULTRAFAST/NONLINEAR DEVICES AND TECHNIQUES

11825 oY Multiphoton-induced polymerization in the fabrication of optical waveguides in polydimethylsiloxane (Invited Paper) [1 1825-24] 
Proc. of SPIE Vol. 11825 1182501-4

\section{Downloaded From: https://www.spiedigitallibrary.org/conference-proceedings-of-spie on 26 Apr 2023
Terms of Use: https://www.spiedigitallibrary.org/terms-of-use}

